\title{
Uji Kepekaan Antibiotik Terhadap Pseudomonas aeroginosa Penyebah Sepsis Neonatorum
}

\author{
Prambudi Rukmono, Reni Zuraida* \\ Unit Perinatologi, RSUD Dr. H. Abdul Moeloek Fakultas Kedokteran Universitas Lampung \\ *Biostatistik Fakultas Kedokteran Universitas Lampung
}

Latar belakang. Kematian neonatal akibat sepsis neonatorum masih sangat tinggi, salah satu kemungkinan disebabkan kegagalan terapi antibiotik. Pseudomonas aeroginosa sebagai salah satu penyebab sepsis neonatorum kemungkinan sudah resisten terhadap beberapa antibiotik.

Tujuan. Mengetahui resistensi Pseudomonas aeruginosa terhadap beberapa antibiotik.

Metoda. Dilakukan penelitian deskriptif dengan desain potong lintang. Populasi target adalah pasien yang dirawat di Unit Perawatan Intensif Level II Neonatal Rumah Sakit Abdul Moeloek Lampung (RSAM), selama periode Juli-Desember 2010. Kriteria inklusi, pasien menunjukkan gejala klinis sepsis neonatorum. Kriteria eksklusi, pasien yang meninggal sebelum diambil spesimennya. Pasien diambil sampel darahnya untuk pemeriksaan biakan. Biakan yang tumbuh dan dicurigai sebagai koloni kuman diidentifikasi. Uji kepekaan dilakukan dengan menggunakan metode Kirby-Bauer (disc diffusion technique). Interpretasi National Committee for Clinical Laboratory Standard.

Hasil. Terdapat 14 jenis antibiotik yang diteliti $\geq 50 \%$ resisten terhadap Pseudomonas aeruginosa seperti ampisilin, eritromisin, amoksisilin, sefuroksim, seftriakson, gentamisin, tetrasiklin, sefadroksil, piperasilin, trimetroprim, tobramisin, kotrimoksazol, nalidiksid, sulfonamid kompleks. Sedangkan 11 macam antibiotik yang diteliti $\geq 50 \%$ sensitif di antaranya meropenem, klindamisin, amikasin, norfloksasin, siprofloksasin, ofloksasin, fosfomisin, seftazidim, netilmisin, kanamisin. Antibiotik lini pertama di Unit Perawatan Intensif Level II Neonatal RSAM yaitu ampisilin dan gentamisin, lini kedua seftazidim dan amikasin sedangkan lini ke tiga adalah meropenem.

Kesimpulan. Pseudomonas aeroginosa telah resisten terhadap 14 jenis antibiotik, sehingga para klinisi harus berhati-hati dalam memilih antibiotik terutama golongan sefalosporin. Sari Pediatri 2013;14(5):332-6.

Kata kunci: antibiotik, Pseudomonas aeroginosa, resistensi

Alamat korespondensi:

Dr. Prambudi Rukmono, Sp.A. Jl. Singosari no 23. Enggal. Tanjung Karang. Bandar Lampung. Telp (0721) 253761, HP: 08117100040/081957000041. E-mail:prukmono@yahoo.com
I

nfeksi pada neonatus masih merupakan penyebab utama mortalitas dan morbiditas pada bayi baru lahir. ${ }^{1}$ Angka kejadian sepsis neonatorum di negara maju 1-5 per 1.000 kelahiran hidup, sedangkan di negara berkembang masih cukup tinggi, yaitu 1,8-18 per 1.000 kelahiran hidup, dan $42 \%$ merupakan 
penyebab utama kematian neonatal. ${ }^{2}$ Di Rumah Sakit Cipto Mangunkusumo Jakarta tahun 2005, infeksi pada bayi baru lahir menjadi penyebab 13,68\% dari seluruh kelahiran hidup dengan angka kematian 14,18\%. ${ }^{3}$ Antibiotik merupakan hal penting dalam penanganan sepsis neonatorum. Penggunaan antibiotik yang luas dan tidak tepat menyebabkan bakteri penyebab sepsis mengalami resistensi. ${ }^{4}$ Bakteri gram negatif yang menjadi perhatian dalam sepuluh tahun terakhir adalah Klebsiella pneumoniae, Acinobacter spesies, Pseudomonas Aeroginosa dan Enterobacter spesies. Bakteri gram negatif tersebut diduga telah banyak yang mengalami multidrug resisten (MDR). Tiga tipe MDR bakteri gram negatif, yaitu extended-spectrum $\beta$-lactamase (ESBL) - producing Enterobacteriaceae, carbapenemase - producing Enterobacteriaceae dan MDR Pseudomonas aeruginosa. ${ }^{4,5,6}$ Pada pengalaman kami, bakteri penyebab sepsis neonatorum yang tersering ditemukan di Unit Perawatan Intensif Level II Neonatal RSAM Lampung adalah Pseudomonasa aeroginosa.

Tujuan penelitian untuk mengetahui resistensi Pseudomonas aeroginosa penyebab sepsis neonatorum terhadap beberapa antibiotik yang sering dipakai. Manfaat penelitian agar hasil penelitian ini dapat dipergunakan untuk mengetahui resistensi Pseudomonas aeroginosa terhadap beberapa antibiotik yang sering dipakai, dan untuk mengantisipasi kemungkinan resistensi Pseudomonas aeroginosa terhadap antibiotik tersebut di kemudian hari.

\section{Metode}

Penelitian dengan desain potong lintang, deskriptif, pada pemeriksaan laboratorium untuk mengetahui resistensi bakteri penyebab sepsis terhadap beberapa antibiotik. Populasi target dalah pasien yang dirawat di Unit Perawatan Neonatal Level II RSAM Bandar Lampung selama periode Juli-Desember 2010. Kriteria inklusi adalah pasien yang masuk ke Unit Perawatan Neonatal level II RSAM Bandar Lampung yang setelah dirawat menunjukkan gejala klinis sepsis neonatorum. Diagnosis sepsis neonatorum ditegakkan berdasarkan gejala gangguan fungsi organ disertai pemeriksaan laboratorium dengan petanda hematologik (septic marker). Septic marker adalah hitung leukosit total, hitung neutrofil, neutrofil imatur, rasio neutrofil imatur dengan neutrofil total (I:T), mikro erythrocyte sedimentation rate (ESR), hitung trombosit, serta CRP. Kriteria eksklusi apabila pasien meninggal sebelum diambil spesimennya. Pencatatan dilakukan terhadap subjek penelitian meliputi karakteristik umum, usia saat masuk, jenis kelamin, dan berat badan. Pada semua pasien diambil sampel darahnya $1 \mathrm{cc}$ dan dimasukkan ke dalam media transport nutrient broth kemudian ditanam dalam media platting untuk pertumbuhan kuman. Biakan yang tumbuh dan dicurigai sebagai koloni kuman diidentifikasi dengan melakukan uji biokimia. Uji kepekaan dilakukan dengan menggunakan metode Kirby-Bauer (disc diffusion technique). Interpretasi yang digunakan menurut National Committee for Clinical Laboratory Standard. Pemeriksaan biakan dan uji kepekaan dilakukan di Laboratorium Kesehatan Daerah Propinsi Lampung (Labkesda) oleh analis dibantu oleh peneliti dan petugas laboratorium RSAM Lampung. Data dicatat pada formulir isian penelitian, kemudian dimasukkan ke dalam program SPSS versi 17.0 selanjutnya dianalisis secara deskriptif dengan tampilan frekuensi dan persentasi.

\section{Hasil}

Didapatkan 81 bayi yang memenuhi kriteria inklusi dan eksklusi, 52 (64\%) bayi di antaranya mempunyai biakan positif. Di antara 52 bayi yang mempunyai biakan darah positif 23 (44\%) spesimen positif terhadap Pseudomonas aeroginosa. Sedangkan sisanya positif terhadap Alkaligenes sp, Staphylococcus sp, Klebsiella, Proteus sp, Enterobacter, E. Coli masingmasing $15,14,11,8,6$, dan $2 \%$.

Selanjutnya pada Pseudomonas aeroginosa dilakukan uji resistensi terhadap beberapa antibiotik. Jumlah antibiotik yang digunakan 25 jenis. Tabel 1 memperlihatkan 14 jenis antibiotik (nomor urut 1-14) didapatkan $\geq 50 \%$ spesimen telah resisten. Antibiotik yang paling resisten adalah ampisilin, eritromisin, amoksisilin, sefurosim, seftriason, gentamicin, tetrasiklin, sefadroksil, piperasilin, trimetroprim, tobramisin, kotrimoksazol, nalidisid, sulfonamidkompleks.

Sementara 11 jenis antibiotik sebagian besar $(\geq 50 \%)$ masih sensitif yaitu dari urutan kloremfenikol sampai meropenem. Adapun untuk golongan sefalosforin, sebagian besar spesimen masih sensitif mulai dari antibiotik yang paling sensitif, berturutturut adalah meropenem, klindamisin, amikasin, 
Tabel 1. Hasil uji resistensi antibiotik

\begin{tabular}{lcc}
\hline \multirow{2}{*}{ Antibiotik } & \multicolumn{2}{c}{ Persentase } \\
\cline { 2 - 3 } & Resisten & Sensitif \\
\hline Ampisilin & 84,6 & 15,4 \\
Eritromisin & 82,7 & 15,4 \\
Amoksisilin & 80,8 & 19,2 \\
Sefuroksim & 76,9 & 23,1 \\
Seftriakson & 71,2 & 28,8 \\
Gentamisin & 71,2 & 28,8 \\
Tetrasiklin & 71,2 & 26,9 \\
Sefadroksil & 67,3 & 30,8 \\
Piperasilin & 63,5 & 36,5 \\
Trimetroprim & 63,5 & 34,6 \\
Tobramisin & 59,6 & 38,5 \\
Kotrimoksazol & 51,9 & 48,1 \\
Nalidiksid & 50,0 & 48,1 \\
Sulfonamid-kompleks & 50,0 & 46,2 \\
Kloramfenikol & 44,2 & 55,8 \\
Kanamisin & 36,5 & 61,5 \\
Netilmisin & 34,6 & 65,4 \\
Seftazidim & 32,7 & 59,6 \\
Fosfomisin & 32,7 & 61,5 \\
Ofloksasin & 30,8 & 69,2 \\
Siprofloksasin & 28,8 & 71,2 \\
Norfloksasin & 26,9 & 73,1 \\
Amikasin & 23,1 & 76,9 \\
Klindamisin & 21,2 & 73,1 \\
Meropenem & 19,2 & 73,1 \\
\hline
\end{tabular}

norfloksasin, siprofloksasin, ofloksasin, fosfomisin, seftazidim, netilmisin, dan kanamisin.

\section{Pembahasan}

Data dari seluruh dunia menunjukkan lebih kurang lima juta kematian neonatal terjadi setiap tahunnya, dan $98 \%$ di antaranya terjadi di negara berkembang, khususnya Asia dan Afrika. Infeksi seperti tetanus, pneumonia, sepsis, meningitis, dan diare berkisar 30\%-50\% dari seluruh kematian neonatal terjadi di negara berkembang tersebut. ${ }^{7}$ Bakteri penyebab sepsis neonatorum terbanyak yang ditemukan di negara berkembang tersebut adalah bakteri gram negatif. ${ }^{8}$ Penelitian yang kami lakukan menemukan lebih dari $70 \%$ bakteri penyebab adalah gram negatif, Pseudomonas aeroginosa (44\%) sebagai bakteri terbanyak ditemukan diikuti Alkaligenes sp (15\%), Stafilococcus sp (14\%) dan Klebsiella (11\%). Hasil yang hampir sama ditemukan oleh penelitian lain, yaitu bakteri gram negatif merupakan bakteri terbanyak yang ditemukan. Joshi $^{8}$ dari India menemukan

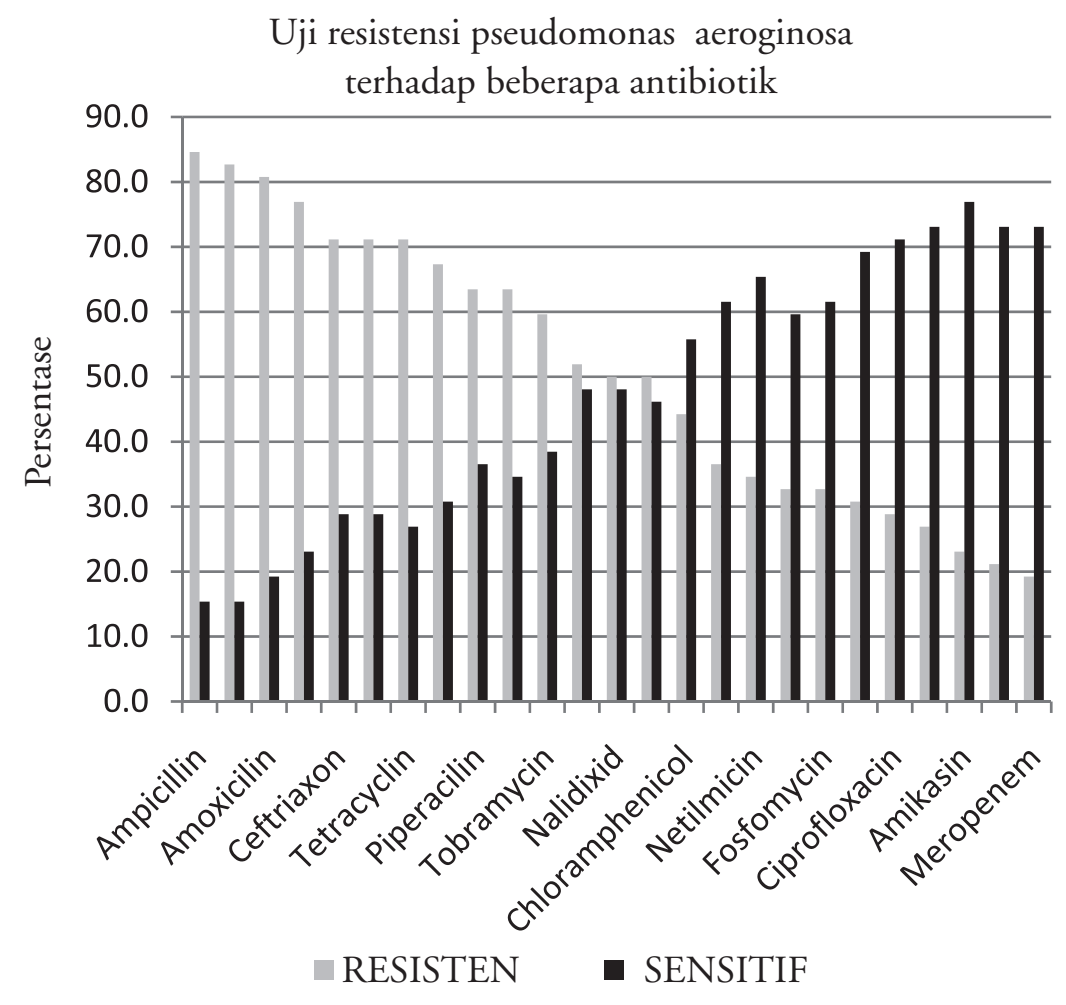

Gambar 1. Hasil uji resistensi Pseudomonas aeroginosa terhadap beberapa antibiotik 
bakteri penyebab sepsis adalah gram negatif $(67,2 \%)$, yaitu Pseudomonas aeroginosa (38,3\%), Klebsiella (30,4\%), dan Escherichia coli (15,6\%). Maryam dan Laeeq $^{9}$ menemukan $80 \%$ bakteri gram negatif yang menyebabkan sepsis, terbanyak adalah Escherichia coli (45,8\%), diikuti Klebsiella (17,2\%), dan Pseudomonas $s p(16,2 \%)$. Kumhar dan Ramachandran ${ }^{10}$ menemukan $60 \%$ gram negatif yang terbanyak adalah Klebsiella $(33,8 \%)$, Enterobacter sp (7,5\%), Alkaligenes fecaelis (4,9\%), dan Escherichia coli (4,6\%). Chaudhury ${ }^{11}$ menemukan $50 \%$ bakteri gram negatif terbanyak adalah Pseudomonas aeroginosa (19,9\%) dari 201 sampel darah positif dari pemeriksaan biakan. Aurangzeb dan Hameed ${ }^{12}$ menemukan Escherichia coli $(77,1 \%)$ yang merupakan bakteri terbanyak diikuti Pseudomonas aeruginosa $(8,9 \%)$ dari 67 sampel darah yang positif. Rahman dan Hameed ${ }^{13}$ menemukan Pseudomonas aeruginosa $(22,4 \%)$ merupakan bakteri gram negatif terbanyak ke dua yang ditemukan setelah Escherichia Coli (36,6\%). Oreett ${ }^{14}$ menemukan Pseudomonas aeruginosa $43 \%$ sebagai penyebab sepsis. Butta dan Yusuf ${ }^{15}$ menemukan Klebsiella adalah bakteri terbanyak penyebab sepsis.

Sepsis neonatorum merupakan salah satu penyebab terbesar kematian pada neonatus, diduga karena bakteri penyebab sepsis telah mengalami resistensi antibiotik. Resistensi antibiotik pada berbagai bakteri sudah menjadi masalah dunia. Hampir 25\%-40\% pasien di rumah sakit mendapatkan antibiotik selama perawatan. ${ }^{4}$ Multiresisten Pseudomonas aeroginosa (MRPA) bila ditemukan lebih dari 3 antibiotik yang resisten dari golongan penisilin, -laktam, kuinolon, aminolgikosid, dan karbapenem. ${ }^{1}$ Penggunaan antibiotik yang sangat luas tidaklah mengherankan bahwa tingkat resistensi kuman terhadap antibiotik semakin meningkat. Pada penelitian kami, ditemukan resistensi Pseudomonas aeroginosa terhadap antibiotik lini pertama ampisilin 84,6\% dan gentamisin 71,2\%. Hasil yang sama ditemukan di Pakistan, yaitu resisten terhadap ampisilin $86,4 \%$ dan gentamisin $78,6 \% .^{10}$ Aurangzeb dan Hameed ${ }^{12}$ menemukan resistensi terhadap ampisilin $79,3 \%$ dan gentamisin $43,2 \%$. Orrett ${ }^{14}$ menemukan resistensi terhadap ampisillin $85 \%$ dan gentamisin $72,1 \%$.

Sementara antibiotik lini kedua pada penelitan kami, ditemukan seftazidim 32,7\% dan amikasin 23,1\% telah resisten terhadap Pseudomonas aeruginosa. Berbeda dengan penelitian yang dilakukan Aurangzeb ${ }^{12}$ di Peshawar Pakistan menemukan resistensi terhadap seftazidim $71,6 \%$ dan amikasin $22,3 \%$. Rahman dan Hameed ${ }^{13}$ di Pakistan melaporkan sefotaksim $73 \%$, seftazidim $56,51 \%$, seftriason $67 \%$. Orret dan Shurland ${ }^{14}$ mendapatkan $76,7 \%$ resisten terhadap seftazidim, sedangkan Kumhar dan Ramachandran ${ }^{10}$ menemukan resistensi 25\% terhadap amikasin. Sebagian besar penelitian di luar negeri, menunjukkan Pseudomonas aeruginosa sudah resisten terhadap seftazidim, akan tetapi pada penelitian kami seftazidim masih sensitif (59,6\%).

Antibiotik lini ketiga pada penelitian ini adalah meropenem (gol imipenem), resistensi Pseudomonas aeruginosa adalah 19,2\%. Sejak 2003 di Amerika ditemukan peningkatan resistensi terhadap karbapenem, dan sudah terjadi dalam sepuluh tahun terakhir ini di beberapa belahan dunia. ${ }^{16}$ Di India, ditemukan karbapenem (gol imipenem) yang mengalami resisten terhadap Pseudomonas aeroginosa $6,6 \% .{ }^{9} \mathrm{Koksal}^{17}$ melaporkan dari 35 kasus sepsis neonatorum yg disebabkan gram negatif dan telah resisten ampisilin, amoksisilin, sefotasim, seftazidim, seftriason dan aminoglikosid, setelah diberikan meropenem 94,3\% mengalami perbaikan secara klinis. Bradley $\mathrm{dkk},{ }^{18}$ menyarankan pemberian meropenem untuk infeksi berat yang disebabkan bakteri gram negatif yang sudah mengalami resistensi terhadap beberapa antibiotik; walaupun penggunaannya harus dipertimbangkan secara cermat. Lutsar dkk, ${ }^{19}$ melakukan penelitian terhadap meropenem dengan dosis $20 \mathrm{mg} / \mathrm{kgBB}$ yang diberikan tiap 12 jam atau 8 jam tergantung usia pasien, ternyata memberikan hasil yang cukup baik secara klinis dalam 3 hari. ${ }^{19}$ Meropenem merupakan antibiotik golongan beta laktam dari grup karbapenem dengan spektrum luas dan merupakan satu-satunya obat grup karbapenam yang tersedia saat ini. ${ }^{20}$ Perlu mendapat perhatian bahwa meropenem pada penelitian kami saat ini masih merupakan antibiotik yang paling sensitif $(71,3 \%)$.

\section{Kesimpulan}

Telah dilakukan uji kepekaan terhadap 25 jenis antibiotik pada Pseudomonas aeroginosa, lebih dari separuh antibiotik yang telah resisten. Oleh karena itu, kepada praktisi kesehatan sangat perlu memperhatikan pemakaian jenis antibiotik terutama golongan sefalosporin yang saat ini masih dianggap poten untuk meningkatkan angka kesembuhan pasien. 


\section{Daftar pustaka}

1. Haque KN. Definitions of bloodstream infection in the newborn. Pediatr Crit Care Med 2005;6:S45-9.

2. Rohsiswatmo R. Kontroversi diagnosis sepsis deonatorum. Dalam: Update in Neonatal Infection. Pendidikan Kedokteran Berkelanjutan IKA XLVIII Jakarta; 2005.h.32-4.

3. Aminullah A. Masalah terkini sepsis neonatorum. Dalam: Update in neonatal infection. Pendidikan Kedokteran Berkelanjutan IKA XLVIII Jakarta;2005.hlm.1-15.

4. Souha S. Kanj, MD, and Zeina A. Kanafani, MD. Current concepts in antimicrobial therapy against resistant gram-negative organisms: extended-spectrum $\beta$-lactamase-producing Enterobacteriaceae, carbapenemresistant Enterobacteriaceae, and multidrug-resistant Pseudomonas aeruginosa. Mayo Clin Proc. 2011;86:2509.

5. Layeux B, Taccone FS, Fagnoul D, Vincent JL, Jacobs F. Amikacin monotherapy for sepsis caused by panresistant Pseudomonas aeruginosa. Antimicrob Agents Chemother 2010;54:4939-41.

6. Kiran S, Sharma P, Harjai K, Capalash N. Enzymatic quorum quenching increases antibiotic susceptibility of multidrug resistant Pseudomonas aeruginosa. Iran. J. Microbiol 2011;3:112.

7. Damstadt GL. Global newborn health challenges and opportunities proceedings of 10 th national nnual Pediatrics Conference 2001 April 20-22; Bhurban: Lahore. Pakistan Paediatrics Association; 2001.h.22.

8. Joshi $\mathrm{Sj}$, Ghole VS, Niphadkar KB. Neonatal gram negative bacteremia. Indian J Pediatr 2000;67:27-32.

9. Maryam W, Laeeq A, Maqbool S. Neonatal sepsis spectrum of antibiotic resistance. Proceeding of 10th Annual National Pediatric Conference 2001 April 2022; Bhurban: Lahore. Pakistan Paediatrics Association; 2001.h.57.

10. Kumhar GD, Ramachandran VG, Gupta P. Bacteriological analysis of blood culture isolates from neonatesin tertiary care hospital in India. J Health Popul Nutr 2002;20:3437.

11. Chaudhury A, Rao TV. Bacteraemia in tertiary care urban hospital in South India. Indian J Pathol Microbiol 1999;42:317-20.

12. Aurangzeb B, Hameed A. Neonatal sepsis in hospitalborn babies: bacterial isolate and antibiotic susceptibility patterns. J Coll Physicians Surg Pak 2003;13:629-32.

13. Rahman S, Hameed A, Roghani MT, Ullah Z. Multidrug resistant neonatl sepsis in Peshawar, Pakistan. Arch Dis Child Fetal Neonatal 2002;87:52-4.

14. Orrett FA, Shurland SM. Neonatal sepsis and mortality in a regional hostpital in trinidad: aetiology nd risk factors. Ann Trop Paediatr 2001;21:20-5.

15. Bhutta ZA, Yusuf K. Neonatal sepsis in Karachi: factors determining outcome and mortality. J Trop Pediatrtr 1997;43:65-70.

16. Chaudhary U, Aggarwal R. Extended spectrum $\beta$-lactamases (ESBL) - an emerging threat to clinical therapeutics. Indian J Med Microbiol 2004;22:75-80.

17. Kolsal N, hacimustafaoglu M, Bagel S. Meropenem in severe infection due to multirestant gram negatif bacteria. Indian J Paediatr 2001;68:15-9.

18. Bradley JS, Garau J, Lode H, Rolston KV, Wilson SE, Quinn JP. Carbapenem in clinical practice: a guide to their use in serious infection. Int J Antimicrob Agenta 1999;11:93-100.

19. Lutsar I, Trafojer UM, Heath PT, Metsvaht T, Standing J, Esposito S, dkk. Meropenem vs standart of care for treatment of late onset sepsis in children of less than 90 days of age: study protocol for a randomised controlled trial. Trials 2011;12:215.

20. Suarez C, Pena C, Arch O, Domingus MA, Tbau F, Carlon J, dkk. A large sustained endemic outbreak of multiresistant Pseudomonas aeruginosa: a new epidemiological scenario for nosocomial acquisition. BMC Infect Dis 2011;11:272. 